\title{
Association between Serum Testosterone and PSA Levels in Middle-Aged Healthy Men from the General Population
}

\author{
Saad Elzanaty ${ }^{\mathrm{a}} \quad$ Babak Rezanezhad $^{\mathrm{b}} \quad$ Gert Dohle $^{\mathrm{c}}$ \\ aDepartment of Translational Medicine, Division of Urological Research, Skåne University Hospital, Lund University, Malmö; \\ bDepartment of Internal Medicine, Skåne University Hospital, Lund, Sweden; 'Department of Urology, \\ Erasmus University Medical Centre, Rotterdam, the Netherlands.
}

\section{Key Words}

Eugonadal • Hypogonadal • PSA • Prostate cancer •

Testosterone

\begin{abstract}
Introduction: The aim of the present study was to evaluate the association between serum testosterone and PSA levels in middle-aged healthy men from the general population. Materials and Methods: Based on 119 healthy men from the general population, total testosterone and PSA levels were measured. Demographic data regarding BMI, waistto-hip ratio, smoking, and alcohol consumption were also collected. Men were classified into two groups according to testosterone levels; hypogonadal (testosterone $\leq 12 \mathrm{nmol} / \mathrm{l}$ ), and eugonadal (testosterone $>12 \mathrm{nmol} / \mathrm{l})$. Results: The mean age of the subjects was 55 years (range 46-60 years). No significant correlation between serum testosterone and PSA levels was found $(p=0.60)$. PSA levels were similar when compared between hypogonadal and eugonadal men (1.4 $\mu \mathrm{g} / \mathrm{l}$ vs. $1.4 \mu \mathrm{g} / \mathrm{l}, \mathrm{p}=0.90$ ). When using a multivariate analysis model adjusted for the age of the subjects, BMI, waistto-hip ratio, smoking, and alcohol consumption, a positive significant association between testosterone and PSA levels was found ( $\beta=0.03,95 \% \mathrm{Cl}=0.003-0.062, p=0.03$ ). Conclusion: Only after adjusted multivariate analysis, our results indicated that testosterone was associated with PSA levels in middle-aged healthy men.

Copyright $\odot 2016$ S. Karger AG, Basel
\end{abstract}

() 2016 S. Karger AG, Basel

Fax +4161306 1234

E-Mail karger@karger.ch

www.karger.com
Accessible online at: www.karger.com/cur

\section{Introduction}

Testosterone is essential for the development of the prostate during early fetal life, and to maintain a trophic and differentiating effect throughout childhood and adult life [1]. PSA is a 240 amino acid serine protease produced by human prostatic epithelial cells; its levels in serum have been correlated with prostate volume and prostate cancer [2, 3].

The regulation of cellular production of PSA is not fully understood. A postulated mechanism regulating PSA production consists of free testosterone being taken up by the prostatic epithelial cells, converted to $5 \alpha$-dihydrotestosterone by $5 \alpha$-reductase type II, binding to the androgen receptor and interacting with the androgen responsive element located upstream from the PSA gene [4-6]. Evidence supporting this mechanism in multiple studies shows a decrease of PSA levels in men with benign prostatic hyperplasia and prostate cancer following androgen deprivation [7].

Understanding the association between testosterone and PSA levels is therefore, important, especially considering testosterone replacement therapy (TRT) and risk of prostatic disorders especially prostate cancer. In this regards, the results of reports regarding testosterone-PSA relationship are inconsistent indicating no association $[8$, 9] or a positive association [10-14]. This discrepancy 
might be attributed to the fact that most of the studies investigated the association between testosterone and PSA were conducted on men receiving TRT [8, 10-14]. Therefore, the aim of the present study is to investigate the association between testosterone and PSA levels in healthy men based on data from 119 middle-aged healthy men from the general population.

\section{Materials and Methods}

This study was based on 119 middle-aged healthy men from the general population in the southern part of Sweden between 2006 and 2008. In brief, an invitation letter was sent to men aged 40 to 60 years in the southern part of Sweden, asking them to participate in a study about male sexual function and subclinical cardiovascular disease. Enclosed in the envelope were two questionnaires regarding their general medical health and sexual function. Men who were interested in taking part in the study were asked to sign a written informed consent and submit it to the Department of Cardiology, Malmö University Hospital along with the completed questionnaires. A medical doctor then examined the completed questionnaires, and men who were found eligible were scheduled for an interview and a thorough medical examination.

The questionnaire return rate was $16 \%(255 / 1,601)$. Of the 255 returned questionnaires, 108 were excluded (mainly due to prevalent cardiovascular disease such as hypertension). Of the remaining 147 men, 28 (19\%) were further excluded, one with pathological echocardiogram, one with abnormal urological findings, 11 that did not want to continue, and 15 that were excluded due to other causes, resulting in 119 healthy men with full medical examinations who were included in this study.

Exclusion criteria were past or present history of medical diseases including psychological diseases, or prescription of regular medications during the last 6 months prior to inclusion. Men outside the range of 40-60 years of age were not included.

Demographic data regarding height, weight, waist circumference, hip circumference, as well as unhealthy habits including smoking and alcohol consumption were also collected. Each man was asked to deliver a blood sample for analysis of total amount of PSA and testosterone. The samples were derived between 07:00 and 10:00 am.

A few men included in the analysis had missing data on one or more of these variables: PSA (11 men) and testosterone (11 men). The main outcome measure was the association between serum levels of testosterone and PSA.

\section{Statistical Analysis}

Statistical analyses were done using the SPSS software version 16 (SPSS, Inc; Chicago, IL). The correlations between testosterone levels, PSA levels, age, BMI, waist-to-hip ratio were performed using the Spearman's rank correlation coefficient test. Men were classified according to testosterone levels into hypogonadal (testosterone levels $\leq 12 \mathrm{nmol} / \mathrm{l}$ ), and eugonadal men (testosterone levels $>12 \mathrm{nmol} / \mathrm{l}$ ) based on the classification by Bhasin et al. [15]. Thereafter, the age of the subjects, BMI, waistto-hip ratio, and PSA levels were compared between groups using
Table 1. Descriptive statistics of the study population

\begin{tabular}{|c|c|c|}
\hline Variables & Mean $( \pm \mathrm{SD})$ or $\mathrm{n}(\%)$ & Range \\
\hline Age (years) & $55( \pm 4.0)$ & $46-60$ \\
\hline \multicolumn{3}{|l|}{ Age groups (years) } \\
\hline $46-50$ & $17(14 \%)$ & - \\
\hline $54-55$ & $33(28 \%)$ & - \\
\hline $56-60$ & $69(58)$ & - \\
\hline BMI $\left(\mathrm{kg} / \mathrm{cm}^{2}\right)$ & $27( \pm 3.0)$ & $20-38$ \\
\hline \multicolumn{3}{|l|}{ BMI groups $\left(\mathrm{kg} / \mathrm{cm}^{2}\right)$} \\
\hline$<25$ & $42(35 \%)$ & - \\
\hline $25.1-29.9$ & $57(48 \%)$ & - \\
\hline$\geq 30$ & $20(17 \%)$ & - \\
\hline Waist-to-hip ratio & $1.0( \pm 0.6)$ & $0.85-1.2$ \\
\hline \multicolumn{3}{|l|}{ Smoking: } \\
\hline Never & $61(52 \%)$ & - \\
\hline Past or current & $57(48 \%)$ & - \\
\hline \multicolumn{3}{|l|}{ Alcohol: } \\
\hline Yes & $99(85 \%)$ & - \\
\hline No & $18(15 \%)$ & - \\
\hline \multicolumn{3}{|l|}{ Biomarkers: } \\
\hline Testosterone (mg/l) & $15( \pm 7.0)$ & $0.6-32$ \\
\hline PSA $(\mu \mathrm{g} / \mathrm{l})$ & $1.4( \pm 1.0)$ & $0.21-6.2$ \\
\hline
\end{tabular}

$\mathrm{BMI}=$ Body mass index PSA $=$ prostate-specific antigen.

the Mann-Whitney U test. Finally, using a multivariate regression analysis model, we tested the association between testosterone levels, and PSA levels as dependent variable when adjusting the analysis for the age of subjects (46-50, 51-55, and 56-60 years), BMI $\left(<25,25.1-29.9\right.$, and $\left.\geq 30 \mathrm{~kg} / \mathrm{cm}^{2}\right)$, smoking (never, past/ current), alcohol consumption (yes, no). P-values below 0.05 were considered statistically significant.

\section{Results}

The characteristics of the study population are summarized in table 1 . There was a weak negative significant correlation between testosterone levels and BMI ( $\mathrm{r}$ $=-0.30, p=0.01)$. The opposite trend was found regarding PSA levels and the age of the subjects $(r=0.30, p=$ $0.01)$. On the other hand, there were no significant correlations between testosterone and PSA levels; testosterone and the age of the subjects; and PSA and BMI ( $p$ > $0.05)$ (table 2).

Men who were classified as being hypogonadal were older and had higher BMI as compared to those who were classified as being eugonadal (56 vs. 55 years, $\mathrm{p}$ $=0.03)$, (28 vs. $\left.26 \mathrm{~kg} / \mathrm{cm}^{2}, \mathrm{p}=0.01\right)$ respectively. On the other hand, waist-to-hip ratio and PSA levels did not differ significantly between groups $(\mathrm{p}=0.09, \mathrm{p}=0.90)$ respectively (table 3 ). 
Table 2. Correlations coefficients (r) between testosterone, PSA levels and the age of subjects; BMI; waist-to-hip ratio from 119 middle-aged healthy men from the general population.

\begin{tabular}{|c|c|c|c|c|c|c|c|c|c|c|}
\hline \multirow[t]{2}{*}{ Variables } & \multicolumn{2}{|c|}{ Age (years) } & \multicolumn{2}{|c|}{ BMI $\left(\mathrm{kg} / \mathrm{cm}^{2}\right)$} & \multicolumn{2}{|c|}{ Wait-to-hip ratio } & \multicolumn{2}{|c|}{ Testosterone $(\mathrm{nmol} / \mathrm{L})$} & \multicolumn{2}{|c|}{ PSA $(\mu \mathrm{g} / \mathrm{L})$} \\
\hline & $\mathrm{r}$ & $\mathrm{p}$ & $\mathrm{r}$ & $\mathrm{p}$ & $\mathrm{r}$ & $\mathrm{p}$ & $\mathrm{r}$ & $\mathrm{p}$ & r & $\mathrm{p}$ \\
\hline Testosterone (nmol/l) & - & 0.10 & - & 0.01 & - & 0.08 & - & - & 0.05 & 0.6 \\
\hline PSA $(\mu \mathrm{g} / \mathrm{l})$ & 0.10 & 0.10 & 0.30 & 0.30 & 0.20 & 0.06 & 0.05 & 0.60 & - & 0 \\
\hline
\end{tabular}

Statistical analysis was done using Spearman's correlations rank. P-values below 0.05 are considered statistically significant.

Table 3. Comparison of age, BMI, level of PSA levels in consider serum levels of testosterone in 119 healthy men from the general population.

\begin{tabular}{llll}
\hline Variables & \multicolumn{2}{c}{ Testosterone $(\mathrm{nmol} / \mathrm{L})$} & $\mathrm{p}$ \\
\cline { 2 - 3 } & $\begin{array}{l}\leq 12 \mathrm{nmol} / \mathrm{l} \\
(\mathrm{n}=34)\end{array}$ & $\begin{array}{l}>12 \mathrm{nmol} / \mathrm{l} \\
(\mathrm{n}=74)\end{array}$ & \\
\hline Age (years) & $56( \pm 4.0)$ & $55( \pm 4.0)$ & 0.03 \\
MBI (kg/cm $\left.{ }^{2}\right)$ & $28( \pm 4.0)$ & $26( \pm 3.0)$ & 0.01 \\
Waist-to-hip ratio & $1.02( \pm 0.1)$ & $0.99( \pm 0.1)$ & 0.09 \\
PSA $(\mu \mathrm{g} / \mathrm{l})$ & $1.4( \pm 1.0)$ & $1.4( \pm 1.0)$ & 0.90 \\
\hline
\end{tabular}

Values are mean $( \pm \mathrm{SD})$. Statistical analyses were done using the Mann-Whitney U test. P-values below 0.05 are considered statistically significant.

In a multivariate regression analysis model adjusted for the age of the subjects, BMI, waist-to-hip ratio, smoking, and alcohol consumption, a weak positive significant association between testosterone and PSA levels was found $(\beta=0.03,95 \% \mathrm{CI}=0.003-0.062, \mathrm{p}=0.03$ ) (table 4).

\section{Discussion}

Based on 119 middle-aged healthy men from general population, a weak positive significant association between testosterone and PSA levels was seen only after adjusting the analysis to the age of the subjects, BMI, waist-to-hip ratio, smoking, and alcohol consumption indicating that serum testosterone was associated with PSA in the middle-aged healthy men.

According to the androgen saturation hypothesis, the human prostate androgen receptor saturation is reached at relatively low testosterone levels. Consequently, restoring circulating testosterone levels to within the nor-
Table 4. Association between serum levels of testosterone and PSA from 119 middle-aged healthy men from the general population.

\begin{tabular}{lllll}
\hline Variables & \multicolumn{4}{c}{ PSA $(\mu \mathrm{g} / \mathrm{l})$} \\
\cline { 2 - 5 } & $\beta$ & $\mathrm{p}$ & $95 \%$ CI lower & $95 \%$ CI upper \\
\hline Testosterone (nmol/l) & 0.03 & 0.03 & 0.003 & 0.062 \\
\hline
\end{tabular}

Statistical analysis was done using multivariate regression analysis model adjusted for the age of men (46-50, 54-55, and 56-60 years); BMI $(<25$, $25.1-29.9$, and $\geq 30 \mathrm{~kg} / \mathrm{cm}^{2}$ ); waist-to-hip ratio; smoking (yes, past/current); alcohol consumption (yes, no). P-values below 0.05 are considered statistically significant. mal physiologic range should have a minimal impact on testosterone-dependent prostate functions including PSA production [16]. The present study demonstrated a weak positive significant association between testosterone and PSA levels using adjusted multivariate analysis. These results are in accordance with previous reports [17]. It is, therefore, reasonable to postulate that testosterone is associated with PSA in healthy men without prostatic disorders.

It has been postulated that PSA levels increased in response to all types of TRT, regardless of whether the testosterone levels were raised endogenously or exogenously [11]. However, other researchers claimed that PSA levels remain stable after normalization of testosterone and that the increased risk of prostate cancer among men with low onset hypogonadism on TRT is not significantly higher than that in the general population [10, $18,19]$. Marks et al. [20] investigated the effect of TRT on prostate tissue and suggested that TRT for 6 months in patients with low onset hypogonadism increased serum testosterone levels to the mild-normal range, but ap- 
peared to have little effect on prostate tissue androgen levels and cellular function. Rhoden et al. [21] evaluated prostatic changes in hypogonadal men with and without high grade intraepithelial neoplasm (PIN), which is considered to be a prostatic precancerous lesion after one year on TRT. There was no significantly greater increase in PSA or increased risk of prostate cancer in men with PIN as compared to men without PIN. Recently, Ory et al. [22] evaluated the effect of TRT among patients with known prostate cancer including 50 men treated with radiation therapy, 22 with radical prostatectomy, 8 managed with active surveillance, 1 with cryotherapy and 1 with high-intensity focused ultrasound after a follow-up period of 41 months. The authors observed a significant slight increase in PSA levels with increasing serum testosterone levels, however no patients were upgraded to higher Gleason score on subsequent biopsies, and none have gone on to definitive treatment. The authors hypothesised that TRT may be oncologically safe in hypogonadal men following definitive treatment or active surveillance for prostate cancer.
The present study has some limitations. Although the men invited were randomly chosen from the general population, the participation rate in this study was only $16 \%$, and one could question whether this group of men was representative for the general population of middle-aged Swedish men. Since no information was available for the men who chose not to reply to on the questionnaires, the characteristics of this group could not be compared to that of the included group of men. However, the results of the present study are still valid and support the hypothesis that testosterone associate PSA levels in healthy men without prostatic disorders.

In conclusion, our results showed no significant correlation between testosterone and PSA levels. However, when using a multivariate analysis model adjusted for the age of subjects, BMI, waist-to-hip ratio, smoking and alcohol consumption, we found a weak positive significant association between testosterone and PSA levels in middle-aged healthy men from the general population.

\section{References}

1 Isaacs JT: Testosterone and prostate; in Nieschlag E, Behre HM (eds): Testosterone: action, deficiency, substitution, ed 3. Cambridge, Cambridge Univeristy Press, 2004, pp347-374.

2 Catalona WJ, Southwick PC, Slawin KM, Partin AW, Brawer MK, Flanigan RC, Patel A, Richie JP, Walsh PC, Scardino PT, Lange $\mathrm{PH}$, Gasior GH, Loveland KG, Bray KR: Comparison of percent free PSA, PSA density, and age-specific PSA cutoffs for prostate cancer detection and staging. Urology 2000; 56:255-260.

3 Beaulac JA, Fry RN, Onysko J: Lifetime and recent prostate specific antigen (PSA) screening of men for prostate cancer in Canada. Can J Public Health 2006;97:171-176.

4 Kokontis J, Takakura K, Hay N, Liao S: Increased androgen receptor activity and altered c-myc expression in prostate cancer cells after long-term androgen deprivation. Cancer Res 1994;54:1566-1573.

5 Murtha P, Tindall DJ, Young CY: Androgen induction of a human prostate-specific kallikrein, hKLK2: characterization of an androgen response element in the 5' promoter region of the gene. Biochemistry 1993;32: 6459-6464.
6 Riegman PH, Vlietstra RJ, van der Korput JA, Romijn JC, Trapman J: Characterization of the prostate-specific antigen gene: a novel human kallikrein-like gene. Biochem Biophys Res Commun 1989;159:95-102.

7 Akakura K, Bruchovsky N, Goldenberg SL, Rennie PS, Buckley AR, Sullivan LD: Effects of intermittent androgen suppression on androgen-dependent tumors. Apoptosis and serum prostate-specific antigen. Cancer 1993; 71:2782-2790.

8 Cooper CS, MacIndoe JH, Perry PJ, Yates WR, Williams RD: The effect of exogenous testosterone on total and free prostate specific antigen levels in healthy young men. J Urol 1996;156:438-441.

9 Mustafa M, Horuz R, Celik M, Kucukcan A: Is there an association between serum prostate-specific antigen values and serum testosterone levels in healthy men? Korean J Urol 2014;55:465-468.

10 Coward RM, Simhan J, Carson CC 3rd: Prostate-specific antigen changes and prostate cancer in hypogonadal men treated with testosterone replacement therapy. BJU Int 2009; 103:1179-1183.
11 Guay AT, Perez JB, Fitaihi WA, Vereb M: Testosterone treatment in hypogonadal men: prostate-specific antigen level and risk of prostate cancer. Endocr Pract 2000;6:132138

12 Morgentaler A, Benesh JA, Denes BS, Kan-Dobrosky N, Harb D, Miller MG: Factors influencing prostate-specific antigen response among men treated with testosterone therapy for 6 months. J Sex Med 2014;11: 2818-2825.

13 Corona G, Boddi V, Lotti F, Gacci M, Carini M, De Vita G, Sforza A, Forti G, Mannucci E, Maggi M: The relationship of testosterone to prostate-specific antigen in men with sexual dysfunction. J Sex Med 2010;7:284-292.

14 Rastrelli G, Corona G, Vignozzi L, Maseroli E, Silverii A, Monami M, Mannucci E, Forti G, Maggi M: Serum PSA as a predictor of testosterone deficiency. J Sex Med 2013;10: 2518-2528.

15 Bhasin S, Woodhouse L, Casaburi R, Singh AB, Bhasin D, Berman N, Chen X, Yarasheski KE, Magliano L, Dzekov C, Dzekov J, Bross R, Phillips J, Sinha-Hikim I, Shen R, Storer TW: Testosterone dose-response relationships in healthy young men. Am J Physiol Endocrinol Metab 2001;281:E1172-1181. 
16 Morgentaler A, Traish AM: Shifting the paradigm of testosterone and prostate cancer: the saturation model and the limits of androgen-dependent growth. Eur Urol 2009; 55: 310-320.

17 Peskoe SB, Joshu CE, Rohrmann S, McGlynn KA, Nyante SJ, Bradwin G, Dobs AS, Kanarek N, Nelson WG, Platz EA: Circulating total testosterone and PSA concentrations in a nationally representative sample of men without a diagnosis of prostate cancer. Prostate 2015;75:1167-1176.

18 Haider A, Zitzmann M, Doros G, Isbarn H, Hammerer P, Yassin A: Incidence of prostate cancer in hypogonadal men receiving testosterone therapy: observations from 5-year median follow up of 3 registries. J Urol 2015; 193:80-86.
19 Raynaud JP, Gardette J, Rollet J, Legros JJ: Prostate-specific antigen (PSA) concentrations in hypogonadal men during 6 years of transdermal testosterone treatment. BJU Int 2013;111:880-890.

20 Marks LS, Mazer NA, Mostaghel E, Hess DL, Dorey FJ, Epstein JI, Veltri RW, Makarov DV, Partin AW, Bostwick DG, Macairan ML, Nelson PS: Effect of testosterone replacement therapy on prostate tissue in men with late-onset hypogonadism: a randomized controlled trial. JAMA 2006;296:2351-2361.
21 Rhoden EL, Morgentaler A: Influence of demographic factors and biochemical characteristics on the prostate-specific antigen (PSA) response to testosterone replacement therapy. Int J Impot Res 2006;18:201-205.

22 Ory J, Flannigan R, Lundeen C, Huang JG, Pommerville P, Goldenberg SL: Testosterone therapy in patients with treated and untreated prostate cancer: impact on oncologic outcomes. J Urol 2016 